\title{
Solovyov's Metaphysics between Gnosis and Theurgy
}

\author{
Aleksandr Gaisin \\ The Graduate School for Social Research, IFiS PAN, 00-330 Warsaw, Poland; gyssin@gmail.com; \\ Tel.: +7953-154-6247
}

Received: 29 September 2018; Accepted: 8 November 2018; Published: 13 November 2018

\begin{abstract}
This article provides a reading of Vladimir Solovyov's philosophy as expressed in his 'Lectures on Divine Humanity' and 'The Meaning of Love'. It seeks to unpack his eclectic thought in order to answer the question of whether there is a Jewish Kabbalistic influence on the Russian thinker amidst his usual platonic, gnostic, and Schellengian tropes. Interested as a young man in Jewish Mysticism, Solovyov fluctuates in his 'Lectures on Divine Humanity' between a platonic reading of Schellengian Gnosticism and some elements of Kabbalistic origin. In 'The Meaning of Love', he develops a notion of love that puts him very close to what Moshe Idel calls 'theosophic-theurgical Kabbalah'. Showing how 'The Meaning of Love' completes the narrative of 'Lectures', we can affirm that there is a certain Christian Kabbalistic line in Solovyov's thought that culminates in his theurgical understanding of love. In this sense, Solovyov might be called a philosophical Marrano as he is certainly a heterodox theosopher that fluctuates between Christian Gnosis and Christian Kabbalah, never assuming a solid identity.
\end{abstract}

Keywords: philosophical theology; heterodoxy; Judeo-Christianity; Russian religious renaissance; Christian Kabbalah; Vladimir Solovyov

The enigmatic and eclectic nature of Solovyov's thought is unveiled if we simply look at the early readings of his philosophy. Already, the Silver Age's thinker and poet Dmitry Merezhkovsky deemed Solovyov as a Gnostic writer, immersed in Christian heresy (Merezhkovsky 1991, p. 117)1, whereas only several years later, Evgenii Trubetskoy, in his fully-fledged study of Solovyov read him as a staunch follower of Schelling (Trubetskoy 1913) ${ }^{2}$. However, more interesting for us is the assessment of Solovyov given by father Vasily Zenkovskiy-one of the first historians of Russian thought - who criticized Solovyov, while never elaborating on his claims, for introducing Jewish 'Magism' into his philosophy (Zenkovsky 1991) ${ }^{3}$. In this essay, I would like to both challenge and affirm Zenkovsky's reading. Based on Solovyov's 'Lectures on Divine Humanity' (1878-81) ${ }^{4}$ and a later essay, 'The Meaning of Love' (1894), I will sketch Solovyov's metaphysics and show that there is

1 Says Merezhkovsky in my translation: 'Solovyov is gnostic, perhaps, the last great gnostic of all Christianity. Of course, he too suggests religious agency, pragmatism, which is, however, unavoidable for any Christian philosophy. Yet it is contemplation that is for him the first action. Theurgy (bogodelanie) stems for Solovyov from theology (bogopoznanie) and not vice versa, as for pragmatics. For him the essence of dogma opens up not firstly to will and only then to reason, but on the contrary it reveals itself firstly to reason and only then to will. He is rationalist just as any gnostic. Not God's will but God's knowledge is for him primarily religion' (Merezhkovsky 1991, p. 117).

2 For a more recent reading that emphasizes Solovyov's indebtedness to Schelling and Gnosticism see Gaidenko's study of Solovyov (Gaidenko 2001, pp. 69-83). One should also mention Aleksei Kozyrev's historical study of Solovyov's possible gnostic influences (Kozyrev 2007).

3 Zenkovsky says that Jewish Kabbalah is the most important mystic influence on Solovyov. Yet he only points out, that in Solovyov's anthropology one can clearly see Kabbalistic and Romantic influences, especially, in his notion of transforming love, which, according to Russian theologian, is purely magical. In general, Zenkovsky follows Trubetskoy's reading of Solovyov's philosophy (Zenkovsky 1991, p. 55).

4 I used a recent edition of the Russian original. Yet the 'Lectures' are available in English as well (Solovyov 1995). 
indeed a possibility to read him as someone definitely influenced by and interested in Jewish Kabbalah. I will go on to say that what prompted Zenkovsky to misread Solovyov as suggesting some sort of magic is, in fact, Solovyov's closeness to, in Moshe Idel's words, theosophical-theurgical Kabbalah (Idel 2005, pp. 214-17). In my sketch of Solovyov's thought, I will show that he indeed fluctuates between Gnostic suspicion towards creation and more theurgical and erotic affirmation of the finite. In my reading, it is precisely the semi-hidden eroticism of his metaphysics that urges Solovyov to make a step from Christian gnosis to Christian Kabbalah. It is exactly this fluctuation between gnostic, Christian, and kabbalistic tropes that allows us to call, in a sense, Solovyov, a philosophical Marrano ${ }^{5}$ whose oeuvre might look prima facie as Orthodox Christian theology but in a more attenuated contemplation, as my article points out, his work contains crypto-Jewish and hidden Gnostic elements that raise the question whether Solovyov assumes any solid theological identity.

Solovyov was not only a philosopher, but also a visionary. In the autobiographical piece 'Three Meetings' (1898) he sets to poetry his three encounters with Sophia. One happened in his early childhood, followed by a second vision years later in London, which called him to go to Egypt and meet Sophia, literally, in the desert. Surprisingly, Solovyov undertook a voyage to Kairo and there happened the final rendezvous with the eternal feminine. The 'Lectures on Divine Humanity' were delivered in Moscow months after the last vision. If the language of the poem sometimes references Goethe's 'Ewig-weibliche', it still has more influences than just that of German literary tradition. In fact, if Solovyov's work is to be defined as 'eclectic', then the story leading to lectures on Divine Humanity truly highlights intellectual influences Solovyov experienced throughout his early life. Well versed in Spinoza from his adolescence, he studied natural sciences in Saint Petersburg for three years, after which he switched to academic philosophy, only to change again shortly after to theology this time at the Moscow Theological Academy. Biographers say that, initially, Solovyov indeed wanted to study 'proper' theology but it was Christian mysticism, mainly the likes of Jacob Boehme, that took his attention in Moscow. While at the academy, Solovyov asked for a study trip to England and went to London, where he read at the British Museum for about a year. His interest there was to study Kabbalistic literature ${ }^{6}$. In Solovyov's words at the library in London, 'Mysterious forces chose my every book; and I read only of Her ${ }^{\prime 7}$.

In the "Lectures on the Divine Humanity", for the first time, Solovyov presents a rare systematic overview of his metaphysics. The starting point for Solovyov's discourse, as he draws openly on both Schelling and Boehme, is the relationship, the interconnection between God and the world. As in the preceding theosophical tradition, to give an account of this relationship, Solovyov's thought postulates and seeks to explain both creation and theogony as intertwined processes (Sholem 1954) ${ }^{8}$. That is, at the beginning the absolute or God exists, encompassing all single things inside itself. In this primordial existence there is no difference between things within the absolute. Solovyov calls this stage of God's being 'substance' and says that its mode of existence is will. In other words, at the dawn of everything, God existed as all-encompassing entity that found, in itself, a will to express itself. So at the next stage, the willing absolute starts positing or emanating (although Solovyov himself avoids this word) ideal platonic forms that constituted Absolute's content. This first creation/emanation is Logos of God, his word, or the second person of the Trinity. Solovyov calls it 'subject' and its mode of existing is ideas or concepts. The last theogonic step is when the posited Logos returns to the absolute as perception.

5 Agata Bielik-Robson defines the term 'philosophical Marrano' as 'a type of thinker $<\ldots>$ who will never break through the Joycean "Jew-Greek, Greek-Jew" confusion, but nonetheless will try to turn it into his advantage' (Bielik-Robson 2014, p. 4). Despite not being a Jew himself Solovyov might be called a thinker of such productive confusion.

6 I take this short intellectual biography of Solovyov from Zenkovky (Zenkovsky 1991, pp. 11-14). In his more up to date study Aleksei Kozyrev points out that the official goal of Solovyov's trip to London was to prepare a monograph on gnosticism. However, he probably divided his time between reading gnostic tractates such as Pistis Sophia and investigating kabbalistic literature in form of Rosenroth's 'Kabbala Denudata'. Solovyov's library cards were lost, so we can only make educated guesses of what exactly he read in the British Museum (Kozyrev 2007, pp. 10-11, 30-33).

7 Translated by Ivan M. Granger. There is a newly published translation of 'Three Meetings' (Solovyov 2008).

8 I base this reading of theosophy on Gershom Sholem's understanding of it (Sholem 1954, pp. 12-14). 
In other words, God, the substance, perceives the emanated ideas or Logos, and this way of being-as a perception of something - constitutes the third stage of process in God and is, accordingly, the third person of the Trinity (Solovyov 2006, p. 141). Solovyov defines it as 'feeling' and its mode of existence as beauty. Solovyov calls such a God 'the living God' (Solovyov 2006, p. 97), which means that he exists as an everlasting process that is present in every single piece of his creation as the positing of more platonic forms continues. It is remarkable that the creation ex nihilo is not even mentioned, and, moreover, is not even possible in such a strict system, in which, at least at this moment, there is no separate place outside Godhead. God emanates forms, which, in turn, open themselves up and posit lesser forms. In this sense, Solovyov regards platonic forms as having their own subjectivity and will (Solovyov 2006, pp. 89-90), that enables them to continue the process of creation and emanate things that existed within them without difference before that, thus, externalizing further the content of the primordial absolute. Another important point of his scheme is that it establishes and promotes a very rigid and strict hierarchy. There are highly consequent and sequenced relations within the personae of God and since the emanated platonic forms, essentially, take part in this process as well, it means that they are also subjects of this hierarchy. Solovyov extends it to the degree that, for him, all problems of the social world might be summarized as coming from the false hierarchies we build. In other words, instead of taking part in the divine order of things, that is oriented on the eternal harmony of an ideal world, we choose to pursue finite and singled goals, putting them above the infinite and divine. To put it differently, metaphysics as knowledge of the hierarchy of being always comes before any scientific disciplines or ethical reasoning. This line of thought is the foundation of his later theocratic utopia: to know the hierarchy of divine forms is to know the right social order in the world below ${ }^{9}$.

Clearly, the backbone of Solovyov's system is a platonic reading of Schelling from whom he borrows some of his terminology—Absolute, Logos as the first emanation—being the most obvious examples ${ }^{10}$. However, there are nuances in Solovyov's thought that might indeed be explained by his early interest in Jewish Kabbalah. One of such details is that the posited forms in Solovyov's system have similarities with the Zoharic tradition of Sephirot, which, in Sholem words, are not intermediary stages between the phenomenal world and Godhead, as neo-platonic emanations are, but rather different phases of God's manifestation (Sholem 1954, pp. 208-10). So are Solovyov's forms: they exist in their own right, not as the spheres revolving around of the unum but rather as the growing tree that continuously externalizes the content of the Absolute bringing about its different attributes. The forms, Solovyov insists, also have their own free will, and, therefore, are in relations to each other ${ }^{11}$. Given that they produce even more forms, their relationship might be, if not overtly sexual, then still erotic. In fact, Solovyov's own claims in his late essay 'The Meaning of Love' are rather supporting such reading: the true love in its real sense, says he, is only possible in the ideal world of forms but not in our fallen phenomenal world, in which we might only learn to see our beloved ones as if they were glimpses of their true ideal selves. In other words, it is exactly Solovyov who says that love exists precisely in the ideal world of forms, and together with it, we might conclude, comes at least erotic desire and longing. Although the cosmoerotic relationship between God's emanations arguably has its roots in the neo-platonic renaissance, there might be a Jewish influence on Solovyov in how he differentiates between love in the human world and true love in the metaphysical realm of forms. The Italian kabbalist David da Vidas, writes Moshe Idel, 'distinguishes between two different modes

9 This insistence on knowledge also provokes Merezhkovsky to call Solovyov gnostic as shown above. In his 'Heterodox Hegel', Cyril O'Reagan argues that Hegel's preference for Eckhart is based on the fact that, for this medieval thinker, God's revelation has a concrete result, is summed up in words, in knowledge and not in some form of loose imagining (O'Reagan 1994, pp. 29-30). Solovyov here displays the same preference: as much as mystic way of knowing is superior to reason, it is so only when it might be summarized in concrete, commanding knowledge.

10 Here I agree with Trubetskoy's reading (Trubetskoy 1913, p. 277).

11 It is not unknown to German Idealism to postulate that God creates through his attributes. Franz von Baader believed that creation happens not directly from God, but from his revealed attributes (Mirror, Wisdom, Being, Idea). He too called these attributes Sephirot (Baader 1987, pp. 205-6). 
of love. One is metaphysical, constituted by processes of attraction and unification between sefirotic elements within the supernal realm, and has nothing to do with human love'. That is, in the realm of God's emanations 'love serves as a virtus unitiva', that attracts and holds the emanations together, whereas the 'personal love is ... ontologically derived from supernal love' (Idel 2005, p. 193). I will return to and analyze Solovyov's conception of love later in the text discussing Sophia.

As is shown in the exposition above, Solovyov's thought so far might be prone to pantheism: the chain of emanations from the absolute is never severed from its source at it were. In fact, he seems to be rather aware of that, and given his indebtedness to Schelling, Solovyov also wants to find ways to protect his own philosophy from being too Schellingian, i.e. pantheistic. Apparently, Solovyov read critiques of Schelling that disapproved his thought as pantheistic (e.g., Franz von Baader). That is, for Schelling in the dialectical process of theogonical world creation, the Absolute posits before itself matter light etc. (Schelling 1994, pp. 118-19). In this respect, as Baader claimed, there is a direct unmediated transition from ideal into material, which ultimately presents a pantheistic world view: certain stages of the Absolute's self-opening happen in the material world and, therefore, God is nature, and, vice versa, nature is God. Solovyov is aware of this problematic and insists that the initial creation consisted exclusively of platonic forms that had nothing to do with the corrupted materiality of the natural world. To defend his own philosophy from pantheistic readings, Solovyov offers several arguments. Firstly, like the persons of the Trinity are defined by their relation to one other, so are the ideal forms defined by their relation to God and to one another. This means, for Solovyov that, strictly speaking, absolutely separated existence would not be possible because it is precisely the shared ground of God and previous creations that binds everything together (Solovyov 2006, pp. 116-18, 130). Although Solovyov does not mention it openly, there are Boehmian ${ }^{12}$ and Schellingian ${ }^{13}$ concepts of unground at play here. Before God awakened and became self-cognizant, everything existed in a state of primordial abyss or unground, just as Solovyov thought, but after his awakening, God is source for every subsequent creation; yet all of what came after this, still shared with God, this first pre-created existence within unground. This doctrine is supposed to give a certain amount of autonomy to the created; Solovyov seems to be counting on it when he later introduces another argument against pantheism by saying that the Absolute exists as both plurality and singleness, otherwise, he insists, it could not be called Absolute after all (Solovyov 2006, p. 160). In this sense, platonic forms are part of God, but they are also subjects that through participating in primordial abyss have the roots of their existence and will within it, and are, therefore, if not equal in their autonomous will and existence, at least analogous to God. This allows Solovyov to say that God is, indeed, all, but all or nature is not God (Solovyov 2006, p. 116). Interestingly enough, in this phrase, Solovyov paraphrases Schelling himself, who defines Spinoza's philosophy saying that God is all that exists but not all that exists is $\operatorname{God}^{14}$. Even more intriguing is that both Schelling and Solovyov are to a degree paraphrasing Moses Cordovero who, as Scholem writes, 'a century before Spinoza and Malebranche', wrote 'that God is all reality, but not all reality is God. En-Sof, according to him (to Cordovero)', continues Sholem, 'can also be called thought (i.e., thought of the world) insofar as everything that exists is contained in His substance. He encompasses all existence, but not in the mode of its isolated existence below, but rather in the existence of the substance, for He and existing things are [in this mode] one, and neither separate nor multifarious, nor externally visible, but rather His substance is present in His Sefhirot, and He Himself is everything, and nothing exists outside Him' (Sholem 1954, p. 253). The Cordoverian argument is not exactly the defence Solovyov presented, but they both stress that because God as En-sof/Absolute had as its content everything that came to be before the emanation took place, there is no true separation afterwards, and the emanated carries God's presence in it, not physically or the way

12 I reference here Nicolas Berdyaev's essay on Jacob Boehme (Berdyaev 1970, pp. vi-xi).

13 Schelling's reading of Unground can be found in his Freiheitsschrift (Schelling 2011).

14 Sholem makes this observation in his 'Major Trends in Jewish Mysticism'. Schelling's phrase can be found in his Muenchener Vorlesungen zur Geschichte der neuren Philosophie (Schelling 1902, p. 44). 
in which ideas/sefhiroth exist, but because everything ever emanated existed before its manifestation within Godhead.

For Solovyov, the initial good creation is constituted fully of ideal platonic forms that exist in eternal harmony with God, expressing and externalizing the Absolute. At this point, there is no material, as opposed to ideal, beings in the Russian thinker's universe. To explain the origin of the finite, real world Solovyov resorts to a very Gnostic ${ }^{15}$ thematic: the world of matter came to being as a result of cosmic catastrophe, and is, therefore, damaged in its essence. It is striking how throughout his Lectures on Divine Humanity, Solovyov repeatedly calls the finite world 'abnormal' as something that should not be in the first place. As much as Solovyov is gnostic while diminishing the value of material world, he does not introduce an evil Gnostic demiurge. He rather again gives a very Neoplatonic reading of Schelling's Abfall ${ }^{16}$, extending and developing it. In his Religion and Philosophy' (1804) the German philosopher argues that the material world splits away from the ideal in a catastrophic event (Schelling 2010, p. 26). Thus, according to Solovyov, the initial ideal creation finds its last stage in what or whom he calls Sophia, 'soul of the world' (Solovyov 2006, p. 173). She is the 'wisdom of God'- the pinnacle of creation - and the platonic form of humanity. As other forms in Solovyov's schematic, Sophia has her own subjectivity and will, i.e. she is free to do whatever she wants. In Solovyov's narrative, although he does not go into pointing out her exact motives, she uses her free will to commit the first crime in the ideal universe of God's emanations: she, instead of following the will of God the substance, wants to be separated, wants to exist on her own without God and outside Him (Solovyov 2006, pp. 192-94). One should look at this motive a bit more closely. Although Solovyov does not use the baroque rhetoric of Boehme, this trope seems to be coming precisely from him. For it is Boehme who describes God the Father as burning fire, righteous anger, and desire, to sin against whom is to deny His will and to put one's own separately ${ }^{17}$. In other words, the sinners rebel against God as they cease to follow His will and be freely subjugated under it. Solovyov, although lacking extravagant images of the shoemaker from Görlitz, still repeats the same argument: the only moral choice in his universe is between accepting the will of the Father or denying it. If one follows the will of God, one accepts his or her place in the harmonic hierarchy of eternal platonic forms. If one denies it, then one must undergo the separation from the pure world of ideas and attempt existence on one's own. Solovyov does not state the reasons or temptations that prompted Sophia to fall and to want herself more than she wanted to fulfil the will of God. However, the fall-in itself-still did not create the material universe as we know it but established the space in which separation between entities was possible. In this space, in the Russian thinker's narrative, everything existed in the state of utter chaos and disarray (Solovyov 2006, p. 196).

At this point, Solovyov's creation story begins, which eclectically mixes Gnostic, Christian, and Kabbalistic tropes. The catastrophe caused by Sophia, in Solovyov's narrative, cannot be overcome at the drop of a hat, which essentially makes both natural and human history a story of reconciliation. Although Schelling remains the ground of this schematic, Solovyov adds some nuances that make it different from the German's idealist perspective. After the fall, says Solovyov, Sophia immediately regrets and wants to restore her unity with God, and in a dramatic gesture, God the Logos plunges into the material space to save Sophia. In other words, God chooses to diminish himself as he enters the material space, so that the fallen creation could be returned to harmony (Solovyov 2006, p. 200).

15 I should clarify my usage of the term 'gnostic' at this point. 'Gnostic' presupposes a stark differentiation or even alienation between true God and the phenomenal world; often a differentiation within Godhead as well would precede the creation of the material world. Gnostic alienation renders the finite, the creation as worthless or damaged and either introduces an evil demiurge, who knowingly or unknowingly rules the finite, or a cosmic catastrophe that creates the lacking finite universe. Either only the souls trapped in the finite universe or the whole world must be saved from its lacking existence, so the gnostic narrative sets up a soteriological view of history.

16 Here, I disagree with Kozyrev's view that Solovyov simply took the notion of split from Valentinian Gnosticism and subsequently transformed its mythology into a philosophical narrative of creation (Kozyrev 2007, p. 76). After all, Schelling is one of the most crucial influences on Solovyov, so one can expect he read 'Philosophy and Religion'.

17 I summarise here again Nikolai Berdyaev's essay on Jacob Boehme (Berdyaev 1970, pp. xi-xviii). 
What is also interesting in Solovyov's kenotic narrative is the fact that the result of God diving into the material world is an erotic, although Solovyov avoids this word, union between Sophia and Logos, that seems to have Kabbalistic overtones. In this union, Sophia, according to Solovyov, is a rather passive, feminine side that receives and apprehends the Logos of God, which is active and carries the ideas that are incarnated in the material universe (Solovyov 2006, p. 201). Together, in their union, Sophia and Logos transform the chaos of the fallen world and co-create the material universe as we know it, first in the process of natural history and then in the moral history of the human race.

This kenotic motive here diminishes Gnostic suspicion towards the material world in Solovyov: the immediate result of the fall is the separation, the empty space between creations, but the phenomenal world is still co-created from this catastrophe in the good will by God and Sophia. In this sense, the finite is not a place where souls are tortured and await salvation that would bring them back to the true world of God, but the finitude has its own merit. In the phenomenal world, in Solovyov's view, we still encounter beauty that mirrors the true grandeur of the ideal realm.

It would help us to understand Solovyov's erotic story of creation if we look again at his later text 'The Meaning of Love', in which he describes a differentiation within God, that establishes his other as the feminine entity: 'God, as one, distinguishing from Himself His other, i.e., all that is not $\mathrm{He}$, unites this all with Himself, presenting it to Himself, all together and all at once, in an absolutely perfect form, and, consequently, as a unity. This other unity, distinct though not separable from the primordial Divine unity, is, relative to God, a passive, feminine unity, seeing that here the eternal emptiness (pure potentiality) receives the fulness of the Divine existence. But if at the basis of this eternal femininity lies pure nothing, then for God this nothing is eternally hidden by the image of the absolute perfection which is being received from the Divinity' (Solovyov 1985, p. 91). One should note that 'pure nothing' in this passage is rather referring to the primordial existence of the Absolute, i.e., things later created had existed beforehand, in Schelling's words, as nothing. In this sense, Sophia existed there in nothingness as an 'inept image' and the creation manifests the concealed potentialities. Says Solovyov, 'For God, His other (i.e., the universe) possesses from all eternity the image of perfect femininity, but He desires that this image should exist not merely for Him, but that it should be realised and incarnated in each individual being capable of union with it. Such a realisation and incarnation is also the aspiration of the eternal femininity itself, which is not merely an inert image in the Divine mind, but a living spiritual being possessed of all the fullness of powers and activities. The whole process of the cosmos and of history is the process of its realisation and incarnation in a great manifold of forms and degrees' (Solovyov 1985, p. 92).

So, God differentiates from Himself His other, which is feminine, and the continuous creation of the world is a task that requires both God and Sophia, which is presented in a state of becoming. The narrative of "The Meaning of Love" does not repeat exactly the story of Sophia's fall that Solovyov tells in Lectures on Divine Humanity, but there is a single core: the differentiation within God is the process of the first creation, and the fullness of the first creation is a feminine entity, together with her God creates later the phenomenal material world. Yet, the split between God and the world, that Solovyov tells us about in Lectures on Divine Humanity, remains open. The finite world is not fully reconciled by actions of God and Sophia with the infinite. In fact, Solovyov says in both his 'Lectures' and in 'The Meaning of Love', it is up to the human race to restore the world in its connection to the eternal. Says Solovyov, 'The power of love, passing into the world, transforming and spiritualising the form of external phenomena, reveals to us its objective might, and after that it is up to us. We ourselves must understand this revelation and take advantage of it, so that it may not remain a passing and enigmatic flash of some mystery. The psycho-physical process of the restoration of the Divine image in material humanity has no means to perfect itself by itself, apart from us' (Solovyov 1985, p. 61). Several pages later, he repeats this in what appears to be more Schellingian rhetoric: 'Our personal concern, so far as it is true, is a common concern of the whole world-the realisation and individualisation of the unity-of-the-all idea and the spiritualisation of matter. It is prepared by the cosmic process in the world of nature and is continued and completed by the historical 
process in humanity' (Solovyov 1985, p. 105). We see that, within this scheme, another Gnostic and Schellingian trope joins Solovyov's narrative: in the process of the creation, it is God who tries to enter to the material world and to make Himself manifest within it. So, says Solovyov in Lectures on Divine Humanity, repeating late Schelling's philosophy, God manifested Himself throughout history as an ideal God in Greek philosophy, as persona in Jewish religion, until finally and literally coming to the world as a new human-Jesus Christ (Solovyov 2006, p. 222).

So the reconciliation between the finite and the infinite is the work of man, and is there any specific path Solovyov might have in mind? In the 'Lectures on Divine Humanity' the answer would be rather in historic terms: the new coming 'complete worldview' 18 , that combines the advances of Western thought together with the pureness of Eastern Orthodoxy will bring about immediate changes to the world. Here, Solovyov is, at first sight, only engaged in romantic messianism, in which the source of eschatological opening is rather not the unspoiled people, but the religious tradition that, in its simplicity, preserved the truth of the early church (Solovyov 2006, pp. 244-45). However, a closer look might argue that his narrative is at least partly Gnostic: it is the philosophy or theology, the knowledge of the eternal harmony of God's world that is to save the finite and reconcile it with the infinite realm of forms. In other words, salvation comes from us knowing and realizing that the phenomenal or 'abnormal' —as Solovyov repeatedly calls material existence — should be brought back into harmony with the ideal ${ }^{19}$. Years later, in 'The Meaning of Love' Solovyov would give another solution. Some of his arguments in this essay fluctuate around monastic or again Gnostic suspicion to anything material: true love is not possible within the phenomenal world and sexual relations are basically not integral to any discussion on love (Solovyov 1985, p. 20). Yet, there is a change in his view that helps humankind to overcome the split between God and the world. Love is what defines existence in the world of platonic forms, so to close the divide and 'spiritualize matter', we should do the same so that it would not be a divided and empty space that defines the existence of the phenomenal world, but the harmony and realization of God's image. Says Solovyov, 'The task of love consists in justifying in deed that meaning of love which at first is given only in feeling. It demands such a union of two given finite natures as would create out of them one absolute ideal personality' (Solovyov 1985, p. 55). That is to say, true love is not possible in this existence, but Solovyov believes that even in its limited scope, it helps to transcend finite reality and shows us glimpses of the real world of forms in our beloved ones. In the lingua of the Christian Church, Solovyov would say that to love would be to perform Christ's commandment from John's Gospel. This altered attitude might be well attributed as that of theurgy. That is, it is our actions in the finite realm that do have a certain effect on the world above and gradually are to undo the catastrophe that the finite world came from. The fact that the world of platonic forms is basically love makes it easy to misread Solovyov as introducing magic in his philosophy. Yet, it is hardly magical as there is no way the action of love commands the infinite or promises any gain or profit for those who perform it. Moreover, it is God's commandment.

In other words, it can be argued that here, Solovyov changes from Gnostic alienation to the creation to a rather theurgic ${ }^{20}$ practical view, and what allows him to make this step is the hidden

18 'Complete worldview' as a description of what is to follow was coined by Sergius Bulgakov in his 'From Marxism to Idealism' (Bulgakov 1903) where he develops his own vision of the synthesis between modern philosophy and theology. He is clearly influenced by Solovyov at that stage.

19 Volens nolens I agree here with Merezhkovsky's verdict on Solovyov shown above.

20 The term originates in Neoplatonism. I use it here, however, more narrowly in the sense in which Moshe Idel calls some trends in Kabbalah as theosophical-theurgical. Says Idel, 'The impact of human performance of the commandments, or of transgressions against them, on the supernal beings, including the sexual union is central to theosophical-theurgical Kabbalah" (Idel 2005, p. 214). Idel further distinguishes what he calls the augmentation model of Kabbalah. In such theurgy, the performance of commandments causes the feminine manifestation to grow, i.e., change for the better. He illustrates this with a story from Zohar, which tells of a forsaken feminine figure who, while separated from her beloved one, becomes "smaller and darker". However, "the powerful men who were her hosts shouted out like 'like strong lions', and the supernal lover heard that she was in love like him. $<\ldots>$ He kissed her and embraced her, and she started to grow, regaining her size and beauty" (Idel 2005, p. 215). According to Idel, the Zoharic author associates 'powerful men' with kabbalists. That is, the growing or diminishing of the Shekhinah is dependent on man. My argument here is that Solovyov proposes a very 
eroticism of his metaphysics. He is, in fact, not a pure Gnostic as he sees good in the finite just as well as his theurgic attitude is also somehow limited-he hides the erotic colors of his thought in the 'Lectures on Divine Humanity' when he calls any descriptions of the relationship between God and Sophia metaphoric; he basically employs ascetic and monastic language ${ }^{21}$ in 'The Meaning of Love'. Curiously, we can read in Alexander Etkind's study of Russian Flagellants influence on the cultural elite of the Empire's last decades, that Solovyov was mocked by Russian Silver Age poet Valery Bryusov, who painted the eschatological last day of the world as a fest gradually slipping into a sexual orgy (Etkind 1998, pp. 177-78) ${ }^{22}$. It is rather a great exaggeration of Solovyov's thought, but I would argue that it only works as a parody precisely because Solovyov thought is in its core erotic ${ }^{23}$.

Of course, to a large degree, Solovyov takes his eroticism from the platonic or Neoplatonic thought. However, it seems that we might also talk about Jewish influence, knowing that he had interest to study Jewish Mysticism in London. First of all, the motive of intra/extra divine differentiation into the female and male that produces the world as the result of their coupling as we have seen it above has its own story in Kabbala. In Moshe Idel's 'Kabbalah and Eros' we read that for R. Yehuda ben Nassim ibn Malka-a 13th century Kabblist-'the Agent Intellect, which emanated directly from the unknown God, is a male entity, and it couples with the cosmic soul, conceived of as female, in order to generate the cosmic hyle' (Idel 2005, p. 183). Idel notes on the same page that, in this case, the influence of Greek philosophy is clearly present and the scheme is different from more theosophical Kabbalah as 'those syzygies are not intradivine powers but extra divine ones'. That is to say, here, the philosophy still outweighs the influence of more religious sources. It is important to argue that Solovyov clearly goes beyond ibn Malka's more simple introduction of theosophical motives into the great scheme of Greek thought. He is, in fact, much closer to the renaissance Jewish thinker Leon Ebreo, who wrote that 'the world was created as the son of the supernal beautiful the father, and the supernal wisdom the mother, or the supernal beauty' (Idel 2005, p. 189). It is here that, although Solvoyov calls the finite world 'abnormal', the fact that the phenomenal world is a child of the God, the Logos, and the eternal feminine beauty of Sophia tells us that there is self-sufficient beauty even in the world as we see it. In other words, the love for finite is more than possible-maybe not so ethically correct for Solovyov-but in the finite we do not see and love Ficino's 'shadows of God' but rather the shards of him that are beautiful by themselves and that need to be returned to $\mathrm{him}^{24}$. In this respect, another non-platonic influence disturbs Platonism in Solovyov-the Eros in his thought takes place in history and not in the endless cycles of nature.

In this sense, the catastrophe that makes God the Logos 'plunge' into the physical space and together with Sophia create the phenomenal universe, is also a form of erotic disjointing between the world of platonic forms and the newly created finite universe. That is, the split away world, itself created as a result of Logos and Sophia coupling, is still cut off from God, and the reconciliation between them is the goal of the world process. In this way, Solovyov sets up a philosophy of history that focuses on describing and predicting various stages of this reconciliation.

The whole Solovyov narrative that views history as a story of curing the catastrophic cosmic event that defined creation, might be read as a development of a motive found in the Lurianic Kabbalah. There, the primordial entities-the 10 Sephiroth—which were to contain the light of God's manifestation and revelation, thus, enabling creation as it should have happened, broke down in

close narrative in "The Meaning of Love". Love, performed by human kind, affects the fallen world, which is the estranged feminine manifestation of God-Sophia—and leads her back to restored union with God.

21 Aleksei Kozyrev offers an analysis of probable gnostic background behind Solovyov's language in 'The Meaning of Love' (Kozyrev 2007, pp. 109-15).

22 The poem is called 'Last Day' and to my knowledge has not been yet translated into English.

23 Evgenii Trubetskoy calls Solovyov's concept of love an 'erotic utopia' (Trubetskoy 1913). Alexei Kozyrev too notices the eroticisation of the divine in Solovyov. For him this signifies a departure from Orthodox theology (Kozyrev 2007, pp. 134-35).

24 My argument is that for Platonic Ficino the mediation is always involved, The 'shadows of God' mediate the true world of divine Unum, whereas for Solovyov the fallen platonic forms are present in the finite world-albeit distorted and damaged—but still worthy of love as they are by themselves. 
the process and as the result of this breaking, our finite world, the way we know it, came into being. This narrative, known as the Breaking of the Vessels, serves as a foundation for a historiosophic view called Tikkun, which renders history as a process in which these vessels are repaired ${ }^{25}$. Given that the imaginary of Kabbalah is often erotic, the Breaking of the Vessels is also a moment of erotic disjointing between the sephirot. It is up to people to repair the vessels and the way to do it is to perform the mitzvah—the religious commandments of Judaism.

As we have seen above, Solovyov's history is also a story of the reconciliation between the finite and infinite, which unfolds in its search for a cure for the cosmic catastrophe. Together with Luria, Solovyov shares the same Gnostic inclinations: the 'abnormality' of the material world; the absence of God in it. However, it seems, that, in Solovyov, his theurgic understanding of love is precisely what makes him less Gnostic. In Solovyov's idioma, seeing a finite loved one as if already reconciled with the eternal world of forms means after all that there is beauty and love, i.e., goodness in this finite realm. Moreover, the fact that it is possible to see and experience beauty and love in the self-enclosed material world that tries to exist on its own outside of God, renders finite as having its own worth. This worth, in Solovyov's view, has of course a relative value and still needs to re-join the Absolute, but it has albeit a limited capacity to stand its own ground. The theurgy, the action here is possible because in its alienation, the world is still affirmed as having been made from the same 'material' as the ideal world of platonic forms, which means that what defines the true world-namely love-is also possible in the finite. In other words, it comes to the fact that, despite Gnostic abnormality of the finite world, there is no absolutely strict distinction or even dichotomy between transcendence and immanence in Solovyov. If action is possible in the finite world, then the pure gnosis-knowledge-is of a less value: it is not enough to just know the laws according to which spirit unfolds in history and matter, but it is rather more important to afflict spirit and, thus, affect history.

In this short sketch of Solovyov's metaphysics, I wanted to show that as much as he is indeed to a large degree defined by Schelling's Gnosticism, there are other voices in his philosophy, and one of these voices is a Jewish one, most likely, thanks to Solovyov's early interest in Kabbalah. What Zenkovskiy rightly called 'Jewish', and wrongly 'Magism', is rather a theurgic attitude to the relationship between God and the world, which unexpectedly alters and fluctuates Solovyov's otherwise Schellingian narrative.

Author Contributions: For research articles with several authors, a short paragraph specifying their individual contributions must be provided.

Funding: This research received no external funding.

Conflicts of Interest: The author declares no conflict of interest.

\section{References}

Baader, Franz. 1987. Vorlesungen über religiöse Philosophie. I Heft. Vom Erkennen. In Sämtliche Werke. Band 1. Aalen: Scientia Verlag, pp. 205-6.

Berdyaev, Nicolas. 1970. Unground and Freedom. In Six Theosophic Points by Jacob Boehme. Translated by John R. Earle. Ann Arbor: The University of Michigan Press.

Bielik-Robson, Agata. 2014. Jewish Cryptotheologies of Late Modernity: Philosophical Marranos. London and New York: Routledge.

Bulgakov, Sergei. 1903. Ot Marksizma kidealizmu: kolleczia esse. Saint Petersburg: Publishing House "Public benefit". Etkind, Alexander. 1998. Hlysty (sekty, literatura i revoluzia). Moscow: Novoe literaturnoe obozrenie, pp. 177-78. Gaidenko, Piama. 2001. Vladimir Solovyov i Filosofia serebryannogo veka. Moscow: Progress-Traditziya, pp. 69-83. Idel, Moshe. 2005. Kabbalah and Eros. New Haven \& London: Yale University Press.

Kozyrev, Aleksei. 2007. Vladimir Solov'ov i gnostiki. Moscow: Savin S.A Private Publishing House.

25 My source here is Sholem's chapter on Luria in his 'Major Trends in Jewish Mysticism' (Sholem 1954, pp. 244-86). 
Merezhkovsky, Dmitry. 1991. Nemoi prorok. In V tihom omute. Statii i issledovaniya raznyh let. Moscow: Sovetskie Pisatel, p. 117.

O’Reagan, Cyril. 1994. Heterodox Hegel. Albany: State University of New-York Press.

Schelling, Friedrich Wilhelm Joseph von. 1902. Schellings Muenchener Vorlesungen zur Geschichte der neuren Philosophie. Edited by Arthur Drews. Leipzig: Meiner Verlag, p. 44.

Schelling, Friedrich Wilhelm Joseph von. 1994. On the History of Modern Philosophy. Translated by Andrew Bowes. Cambridge: Cambridge University Press.

Schelling, Friedrich Wilhelm Joseph von. 2010. Religion and Philosophy. Translated by Klaus Ottoman. Putnam: Spring Publications, p. 26.

Schelling, Friedrich Wilhelm Joseph von. 2011. Über das Wesen der menschlichen Freiheit. Edited by Herausgegeben von Thomas Buchheim. Leipzig/Hamburg: Felix Meiner Verlag.

Sholem, Gershom. 1954. Major Trends in Jewish Mysticism. New York: Shocken Books.

Solovyov, Vladimir. 1985. The Meaning of Love. Translated by Thomas R. Beyer Jr.. London: Lindisfarne Books.

Solovyov, Vladimir. 1995. Lectures on Divine Humanity. Translated by Peter Zouboff. Revised and Edited by Boris Jakim. New York: Lindisfarne Press.

Solovyov, Vladimir. 2006. Chtenia o bogochelovechestve. Moscow: Publishing house AST Moscow.

Solovyov, Vladimir. 2008. The Religious Poetry of Vladimir Solovyov. Translated by Boris Jakim, and Laura Magnus. San Rafael: Semantron Press.

Trubetskoy, Evgenii. 1913. Mirososerzanie Vl. S. Solovyova. Moscow: Publishing house Put'.

Zenkovsky, Vasily. 1991. Istoria Russkoi Filosofii. Tom 2. Leningrad: EGO.

(C) 2018 by the author. Licensee MDPI, Basel, Switzerland. This article is an open access article distributed under the terms and conditions of the Creative Commons Attribution (CC BY) license (http:// creativecommons.org/licenses/by/4.0/). 